Re-use of collateral in the repo market

Lucas Marc Fuhrer, Basil Guggenheim and Silvio Schumacher

SNB Working Papers

2/2015 


\section{Legal Issues}

\section{DISCLAIMER}

The views expressed in this paper are those of the author(s) and do not necessarily represent those of the Swiss National Bank. Working Papers describe research in progress. Their aim is to elicit comments and to further debate.

\section{COPYRIGHT@}

The Swiss National Bank (SNB) respects all third-party rights, in particular rights relating to works protected by copyright (information or data, wordings and depictions, to the extent that these are of an individual character).

SNB publications containing a reference to a copyright (C) Swiss National Bank/SNB, Zurich/year, or similar) may, under copyright law, only be used (reproduced, used via the internet, etc.) for non-commercial purposes and provided that the source is mentioned. Their use for commercial purposes is only permitted with the prior express consent of the SNB.

General information and data published without reference to a copyright may be used without mentioning the source. To the extent that the information and data clearly derive from outside sources, the users of such information and data are obliged to respect any existing copyrights and to obtain the right of use from the relevant outside source themselves.

\section{LIMITATION OF LIABILITY}

The SNB accepts no responsibility for any information it provides. Under no circumstances will it accept any liability for losses or damage which may result from the use of such information. This limitation of liability applies, in particular, to the topicality, accuracy, validity and availability of the information.

ISSN 1660-7716 (printed version)

ISSN 1660-7724 (online version)

(C) 2015 by Swiss National Bank, Börsenstrasse 15,

P.O. Box, $\mathrm{CH}-8022$ Zurich 


\title{
Re-use of collateral in the repo market*
}

\author{
Lucas Marc Fuhrer ${ }^{\dagger}$ \\ Swiss National Bank \\ University of Zurich
}

\author{
Basil Guggenheim $\ddagger$ \\ Swiss National Bank
}

Silvio Schumacher ${ }^{\S}$

Swiss National Bank

University of Bern

January 2015

\begin{abstract}
This paper introduces a methodology to estimate the re-use of collateral based on actual transaction data. With a comprehensive dataset from the Swiss franc repo market we are able to provide the first systematic empirical study on the re-use of collateral. We find that re-use was most popular prior to the financial crisis, when roughly $10 \%$ of the outstanding interbank volume was based on re-used collateral. Furthermore, we show that re-use increases with the scarcity of collateral. By giving an estimate of collateral re-use and explaining its drivers, the paper contributes to the ongoing debate on collateral availability.
\end{abstract}

JEL Classification: D47, E58, G01, G18, G21, G32

Keywords: Re-use of collateral, repo, money market, financial stability, Switzerland.

*The authors are indebted to Beatrice Baenziger, Fabrice Collard, Darrell Duffie, Cornelia Holthausen, Sébastien Kraenzlin, Daniel Kromer, Cyril Monnet, Benjamin Müller, Thomas Nellen, Klaus Neusser, Kjell Nyborg, Steven Ongena, Lidia Schmidt, Jiri Woschitz and Theo Wyrsch for valuable discussions. We are also grateful for comments from seminar participants at the 9th Annual Central Bank Workshop on the Microstructure of Financial Markets, the Annual Congress 2014 of the Swiss Society of Economics and Statistics, the SFI Corporate Finance Workshop 2014, the Brown Bag Lunch Seminar organised by the Department of Banking and Finance at the University of Zurich, the PhD Seminar at the University of Bern and the Money Market and Foreign Exchange Brown Bag Seminar at the SNB. The authors also thank the anonymous referee for valuable comments and suggestions. The views expressed in this paper are those of the authors and do not necessarily represent those of the Swiss National Bank.

${ }^{\dagger}$ E-mail: lucas.fuhrer@snb.ch

‡E-mail: basil.guggenheim@snb.ch

$\S$ E-mail: silvio.schumacher@snb.ch 


\section{Introduction}

Up to now, central banks and regulators have lacked evidence on the re-use of collateral, although this issue has been at the top of regulators' policy agenda (Financial Stability Board, 2012a) and regardless of the impact that collateral re-use might have. Especially, the re-use of collateral has yet not been estimated and analysed based on actual transaction data.

This paper aims to address this issue. First, we estimate the re-use activity in an interbank repo market by developing an algorithm which identifies re-used collateral based on actual transaction data. Second, we analyse the drivers of collateral re-use. We especially focus on the availability of securities, as re-using collateral allows banks to conduct transactions regardless of a potential collateral constraint. Analysing this relationship is of particular interest because current regulatory initiatives have caused an intense debate on collateral availability. Specifically, positive aspects of the re-use of collateral have been emphasised as an increasing reuse may reduce a potential scarcity of collateral (e.g. Levels and Capel (2012) and Committee on the Global Financial System (2013)).

With the experience of the financial crisis, analysing the market for liquidity and especially the repo market is of first order relevance (Fecht, Nyborg, and Rocholl, 2011). Theoretical and empirical literature has documented and dealt with the important role of margin requirements, fire sales and potential rollover risks (e.g. Gorton and Metrick (2012, 2010a,b), Brunnermeier and Pedersen (2009), He and Xiong (2012) as well as Hördahl and King (2008)). Further, empirical studies of the structure of repo markets were provided for example by Copeland, Martin, and Walker (2011) for the US tri-party, by Mancini, Ranaldo, and Wrampelmeyer (2013) as well as Bindseil, Nyborg, and Strebulaev (2009) for the Eurozone and by Kraenzlin (2007) for the Swiss franc (CHF) repo market.

In contrast, literature on the re-use of collateral is rare. Aitken and Singh (2009) and Singh (2011) have estimated the magnitude of collateral rehypothecation. They find evidence for a considerable amount of rehypothecation prior to the financial crisis and a rapid decline after Lehman's bankruptcy. However, rehypothecation cannot be put on par with re-use. The Financial Stability Board (2012b) defines rehypothecation as "the right by financial intermediaries to sell, pledge, invest or perform transactions with client assets they hold" and the re-use of collateral as "securities delivered in one transaction [that] are used to collateralise another transaction". Thus, the right to re-use securities arises in a repo transaction automatically and does not need to be explicitly granted by the collateral provider.

The CHF repo market qualifies for a thorough analysis of the re-use of collateral as the re-use is not restricted, neither technically, legally nor economically. Having a comprehensive dataset from the CHF interbank repo market at our disposal allows us, for the first time, to estimate and analyse the re-use of collateral by considering individual transactions. Additionally, the dataset spanning from March 2006 to February 2013 enables us to analyse the re-use for different time periods such as before, during and after the financial crisis.

Our findings can be summarised as follows. Market participants in the CHF repo market re-use collateral. The re-use activity remained relatively constant until mid-2007 when roughly 
$10 \%$ of the outstanding volume was secured with re-used collateral. Afterwards, it increased and reached its highest value in autumn 2007, at almost 20\%. In 2008, the re-use activity suddenly declined to a very low level and remained there afterwards. The collateral re-used typically originates from a long-term repo (one month and longer) and is used in a short-term transaction. Overall, the extent of re-use within the CHF repo market segment is rather low compared to the findings by Singh (2011) and Aitken and Singh (2009). However, in contrast to these authors, we only evaluate the re-use in CHF repo transactions i.e. a specific market segment and currency. ${ }^{1}$

Based on a logit regression model we assess the drivers of collateral re-use. We find that the re-use of collateral increases with the scarcity of collateral, i.e. it decreases when the collateral availability increases. This goes along with the evidence that the re-use in the interbank market is positively related with the general securities borrowing activity of banks. Hence, banks simultaneously re-use collateral in the interbank market and borrow securities from clients. Further, we find evidence for a significant impact of the maturity of the transaction on the re-use probability. Banks re-use collateral if they lend cash long-term and borrow cash shortterm. This allows them to keep a relatively small pool of securities when, for example, playing the yield curve.

Our findings have important implications for policy makers, regulators and central banks. The measure presented for the re-use of collateral can be used as an indicator for collateral scarcity and financial stress. By explaining the drivers and determinants of collateral re-use, we further create a solid foundation for a discussion about financial stability concerns and market efficiency related to the re-use of collateral. We also show that if collateral scarcity increases, banks will have an incentive to re-use collateral, which in turn increases leverage and interconnectedness in financial markets. In the light of stricter standards for initial margin requirements for over-the-counter derivatives transactions or the liquidity coverage ratio, regulators have to take into account the fact that these regulatory initiatives might increase collateral scarcity and, according to our findings, the re-use of collateral.

The remainder of this paper is structured as follows. Section 2 provides an overview of the institutional setup of the CHF repo market, while in section 3 the algorithm to determine repo transactions with a collateral re-use is explained. Section 4 discusses stylised facts about the re-use activity. Section 5 applies an econometric analysis to evaluate the factors determining collateral re-use. Finally, section 6 concludes.

\section{Institutional setup}

\subsection{Characteristics of the CHF repo market}

Until April 2014, CHF interbank repo transactions in Switzerland were mostly traded on the Eurex Repo trading platform, which was launched in 1999 (Kraenzlin and von Scarpatetti,

\footnotetext{
${ }^{1}$ Collateral could, for example, also originate from a CHF repo transaction and then be re-used in a foreign currency repo transaction or even as an initial margin for an over-the-counter derivatives transaction.
} 
2011). ${ }^{2}$ The trading platform was set up as a non-anonymous market with bilateral trade relationships. The clearing and settlement systems and the trading platform together constitute the Swiss value chain - an infrastructure that allows the complete electronic integration of trading, clearing and settlement. The settlement is thereby based on the delivery versus payment mechanism and takes place in central bank money on the real-time gross settlement system for CHF - the Swiss Interbank Clearing (SIC) - and on the Swiss securities settlement system (SECOM).

To obtain access to the CHF repo market, the participants must have a SIC settlement account, which requires a sight deposit account at the SNB. Consequently, the number of participants in the CHF repo market depends on the access policy of the SNB. Compared to other central banks, the SNB has followed a liberal access policy (Kraenzlin and Nellen, 2014). Beside banks domiciled in Switzerland, banks domiciled abroad and certain non-banks (e.g. domestic insurance companies) are eligible for a sight deposit account at the SNB (Swiss National Bank, 2010). The liberal access policy of the SNB contributed to the steady increase in the number of participants in the CHF repo market - from 37 in 1999 to more than 170 in 2011. Similarly, the outstanding volume in the interbank repo market also increased significantly. It reached its peak in September 2008 after the collapse of Lehman Brothers. At that time, the outstanding volume was about CHF 74 billion (bn).

\subsection{Collateral standards in the interbank market}

In the CHF repo market, almost all interbank repo transactions (more than 99\%) are traded against a collateral basket (i.e. general collateral repos - GC repos). The main motivation for a GC repo is to get cash and not a specific security, whereas the cash provider's interest is to lend without counterparty risks (Bank of England, 2012).

In the CHF repo market, the collateral standards for interbank transactions are the same as for central bank repos. In more than $95 \%$ of all $\mathrm{CHF}$ interbank repo transactions money is exchanged against securities from the collateral basket, which is defined by the SNB (SNB GC basket). Compared to other central banks, the SNB's collateral framework is rather liberal regarding eligible currencies but quite restrictive concerning the quality of the securities (Kraenzlin and Nellen, 2014). ${ }^{3}$ The minimum credit rating for eligible securities is AA- (A) for securities denominated in foreign currencies (in CHF). The minimum liquidity requirement is an issuance volume of at least $\mathrm{CHF} 1 \mathrm{bn}$ (CHF $0.1 \mathrm{bn}$ ) for securities denominated in foreign currencies (in CHF). Eligible securities can be denominated in CHF, EUR, USD, GBP, DKK, SEK and NOK (Swiss National Bank, 2007). The SNB GC basket currently contains about 2,700 different securities worth CHF 9,500 bn. As the SNB GC basket is subject to daily modifications (i.e. due to new issues, redemptions and exclusions), smaller fluctuations in the size of the basket occur.

One of the main differences between the CHF repo market and other repo markets is the

\footnotetext{
${ }^{2}$ As of 1 May 2014 interbank repo transactions are mostly conducted on the new SIX Repo trading platform.

${ }^{3}$ The SNB changed its collateral framework as of 1 January 2015. In the following the criteria valid until the end of 2014 are stated.
} 
absence of haircuts in the former. This means that, irrespective of the characteristics of the collateral delivered (e.g. asset type or currency of denomination), the cash amount is always covered by a security position with an identical market value.

\subsection{The legal, technical and economic setup for re-use}

The Swiss framework agreement on repo transactions and the PSA/ISMA global master repurchase agreement (GMRA) with Swiss annex form the legal basis for any repo transaction in the CHF repo market (Swiss National Bank, 2004). Both agreements state that with the transfer of collateral the parties transfer the full and unencumbered legal ownership of the security. Securities transferred in a repo are thus free of any rights of third parties. Additionally, in standard repo contracts the parties typically agree not to grant the right of substitution. Early termination is theoretically possible but not allowed in most standard contracts (Swiss Bankers Association, 1999). The re-use of securities in the CHF interbank market is therefore not restricted by any legal aspects. Further, the re-use of collateral is technically feasible in the securities settlement system (see appendix for a detailed description).

From an economic point of view, a collateral re-use can only occur if the cash taker has outstanding volume as a cash provider (i.e. received collateral) at the same time. As the CHF repo market is a market with bilateral trade relationships, one can expect two groups of institutions to re-use collateral: market makers acting as cash provider as well as cash taker at the same time and institutions that regularly lend cash long-term and refinance themselves short-term. ${ }^{4}$ While in the former case the re-use is typically conducted in the same maturities, the re-use in the latter case is rather done in overnight, tom-next or spot-next maturities (i.e. day2day maturities). In both cases it is rational to assume that banks might re-use collateral to reduce their own funding collateral needs (own securities used).

\subsection{The bank's pool of securities}

The availability of securities plays a crucial role for banks, especially in the secured money market. Without re-use, a given pool of available securities constrains the maximum possible turnover in the repo market, thus hampering the efficient allocation of liquidity. ${ }^{5}$

Table 1 shows the securities holdings of banks domiciled in Switzerland. By the end of 2012, Swiss banks held a stock of securities worth CHF 262 bn (9.4\% of the total balance sheet) in trading portfolios and as a financial investment. Prior to the financial crisis, banks held roughly the double, worth CHF 555 bn ( $17.4 \%$ of the total balance sheet).

The share of securities holdings that are eligible for SNB repos increased from about $12 \%$

\footnotetext{
${ }^{4}$ Market makers are defined in the federal act as institutions quoting for a specific instrument bid and offer prices for different maturities publicly or upon request (art. 3 para. 4 of the Swiss stock exchange ordinance). The typical market maker thus runs large but matched books and generates profits by charging a spread between bid and offer prices.

${ }^{5}$ Since the outbreak of the financial crisis banks have significantly shifted their exposures from unsecured to secured markets, which consequently increased the demand for collateral (Guggenheim et al., 2011).
} 
to about $45 \%$ in 2010 but decreased again in 2011 and $2012 .{ }^{6}$ A significant share of the SNB eligible securities was held in the custody cover account "SNB" for the liquidity-shortage financing facility (LSFF) and was consequently not available for interbank repos as they can only be used for standing facility repos (Swiss National Bank, 2008). Taking the LSFF holdings into account, the securities available for CHF interbank repos fluctuate between CHF 50 bn and CHF 108 bn.

Table 1: Securities holdings of banks domiciled in Switzerland

\begin{tabular}{lrrrrrrr}
\hline \hline & 2006 & 2007 & 2008 & 2009 & 2010 & 2011 & 2012 \\
\hline Total securities holdings & 555,214 & 551,003 & 298,703 & 309,895 & 321,493 & 266,825 & 261,764 \\
In \% of total balance sheet & $17.4 \%$ & $15.9 \%$ & $9.7 \%$ & $11.6 \%$ & $11.8 \%$ & $9.6 \%$ & $9.4 \%$ \\
Securities borrowing & 237,257 & 271,875 & 97,549 & 78,728 & 66,259 & 57,208 & 51,439 \\
SNB eligible securities & 64,877 & 96,995 & 115,237 & 127,683 & 145,394 & 91,932 & 84,088 \\
In \% of total securities & $11.7 \%$ & $17.6 \%$ & $38.6 \%$ & $41.2 \%$ & $45.2 \%$ & $34.5 \%$ & $32.1 \%$ \\
Held in LSFF* & 12,100 & 33,700 & 34,500 & 35,900 & 37,500 & 32,900 & 33,700 \\
Available securities** & 52,777 & 63,295 & 80,737 & 91,783 & 107,894 & 59,032 & 50,388 \\
\hline \hline
\end{tabular}

In CHF million; * Liquidity-shortage financing facility

**Available securities for repos $=$ SNB eligible - held in LSFF

Source: SNB statistical publications, "Banks in Switzerland"; SNB accountability reports.

\section{Methodology}

To estimate the re-use of collateral in the CHF repo market, we use transaction data from the Eurex Repo trading platform and the corresponding collateral information from SECOM. Only the combination of these two datasets allows an analysis of the re-use of collateral. The repo dataset includes for each transaction the transaction id, cash taker id, cash provider id, purchase date, repurchase date and collateral basket. The collateral dataset includes the transaction id, the ISIN of delivered collateral and the respective market value. The transaction id links the repo dataset with the collateral dataset.

A repo transaction can be covered by several securities. In our sample, on average about three securities have been used per repo transaction. We analyse these collateral transactions in the following. For this reason, we usually report statistics in terms of collateral transactions rather than repo transactions.

To identify collateral transactions with re-used collateral we developed an algorithm that was written in MATLAB and works as follows. First, the algorithm sorts the dataset by purchase date (in ascending order) and duration of the repo transaction (in descending order), i.e. starting with the oldest purchase date and the longest duration. Second, the algorithm iterates over each transaction included in the dataset and checks whether the following conditions hold for all subsequent transactions:

- identical securities (ISINs) are used in both transactions (initial and re-use);

\footnotetext{
${ }^{6}$ This increase might have been in part due to the SNB's issuance of own debt register claims (SNB Bills in CHF and USD) from 2008 until 2011, which are part of the SNB GC basket.
} 
- the collateral provider in the second transaction (re-use) is the same as the collateral taker in the first transaction (initial);

- the repurchase date of the second transaction (re-use) is not later than the repurchase date of the first transaction (initial).

If these three conditions are fulfilled, the first repo transaction is flagged as a possible initial transaction and the second one as a possible re-use transaction. In the last step, the algorithm reduces the probability of overestimation. A transaction can be the initial transaction of several re-use transactions. However, as soon as the collateral value of the initial transaction is used up by re-use transactions, possible subsequent re-use transactions are no longer flagged as re-use transactions. ${ }^{7}$

The algorithm underestimates the re-use of collateral in the first months of the observation period, as we do not observe initial transactions before March 2006. With maturities of up to one year, there is a potential underestimation during the first twelve months. As $97.5 \%$ of all transactions have a maturity of up to three months, we expect the underestimation to be severe only during the first three months of the dataset. Therefore, we exclude this period from our re-use analysis. The fungibility of ISINs and the necessity of the repurchase condition are discussed in the appendix.

\section{Stylised facts about re-use activity}

\subsection{Descriptive statistics}

The analysed period lasts from 1 June 2006 until 28 February 2013 containing 161,108 repo transactions and 470,823 collateral transactions. During the sample period, repo transactions worth about CHF 11.6 tn were settled. Overall, 162 different institutions were active in at least one transaction. On an average trading day roughly 240 (before September 2008), respectively 140 (after September 2008) different ISINs have been used. ${ }^{8}$

Of the 470,823 collateral transactions, 246,271 transactions were performed by cash takers who had an outstanding volume as cash provider at the same time. Note that only those transactions could be secured with re-used collateral. Having applied the methodology described in the previous section, we identified 21,370 collateral transactions ( $4.5 \%$ of all transactions) serving as initial transactions for at least one re-use. Moreover, we identified 87,503 re-use transactions ( $18.6 \%$ of all transactions). ${ }^{9}$ This implies that the collateral from one initial transaction was re-used on average four times (see table 2).

As illustrated in figure 1, re-use transactions contributed on average to about CHF 2.2 bn of the total outstanding volume of CHF 33.9 bn. 108 market participants re-used collateral in

\footnotetext{
${ }^{7}$ The algorithm does not flag a re-use due to a too low initial value in $10 \%$ of the matches.

${ }^{8}$ See also figure 7 , which indicates that there are no security-specific re-use effects.

${ }^{9}$ These re-use transactions may also have originated from initial transactions before 1 June 2006 . Note that table 2 shows re-use transactions based on initial transactions after 1 . June 2006, only.
} 
Table 2: Number of initial and re-use transactions

\begin{tabular}{lrrrrrrr}
\hline \hline \# of re-use & 1 & 2 & 3 & 4 & 5 & $\geq 6$ & Total \\
\hline Initial transaction & 8,352 & 3,893 & 2,352 & 1,538 & 1,079 & 4,156 & 21,370 \\
Re-use transaction & 8,352 & 7,786 & 7,056 & 6,152 & 5,395 & 50,430 & 85,171 \\
In \% all re-use transactions & $9.8 \%$ & $9.1 \%$ & $8.3 \%$ & $7.2 \%$ & $6.3 \%$ & $59.2 \%$ & $100.0 \%$ \\
\hline \hline
\end{tabular}

at least one transaction, whereas the most active five market participants contributed to $31 \%$ of all re-use transactions.

Table 3 shows that the typical re-use occurs with collateral originating from rather long-term repos (1M-3M maturities) that is re-used in short-term repos. In other words, the probability of re-use increases with the duration of the initial transaction. Especially for transactions with a maturity of three months and more the re-use probability increases significantly. Irrespective of the maturity of the initial repo, most of the collateral, i.e. $84 \%$, is re-used in day2day repo transactions.

Table 3: Distribution of re-use by maturity of initial (rows) and re-use (columns) transaction

\begin{tabular}{lrrrrrrr}
\hline \hline & day2day* & $1 \mathrm{~W}$ & $1 \mathrm{~W}-1 \mathrm{M}$ & $1 \mathrm{M}-3 \mathrm{M}$ & $3 \mathrm{M}-6 \mathrm{M}$ & $6 \mathrm{M}-12 \mathrm{M}$ & Total \\
\hline day2day* & $100.0 \%$ & - & - & - & - & - & 2,957 \\
$1 \mathrm{~W}$ & $95.3 \%$ & $4.7 \%$ & - & - & - & - & 5,764 \\
$1 \mathrm{~W}-1 \mathrm{M}$ & $88.1 \%$ & $7.2 \%$ & $4.7 \%$ & - & - & - & 32,140 \\
$1 \mathrm{M}-3 \mathrm{M}$ & $81.7 \%$ & $8.7 \%$ & $8.5 \%$ & $1.2 \%$ & - & - & 32,347 \\
$3 \mathrm{M}-6 \mathrm{M}$ & $71.3 \%$ & $9.0 \%$ & $13.1 \%$ & $6.3 \%$ & $0.4 \%$ & - & 12,534 \\
$6 \mathrm{M}-12 \mathrm{M}$ & $86.3 \%$ & $5.8 \%$ & $4.3 \%$ & $2.4 \%$ & $1.2 \%$ & $0.0 \%$ & 1,761 \\
Total & $84.2 \%$ & $7.6 \%$ & $6.8 \%$ & $1.4 \%$ & $0.1 \%$ & $0.0 \%$ & 87,503 \\
\hline \hline
\end{tabular}

* day2day maturities are: overnight, tom-next, spot-next

\subsection{Measures of collateral re-use}

To describe the magnitude of collateral re-use, different measures have been used so far in the economic literature. In this paper we present two measures to describe the re-use of collateral: the re-use rate and the collateral multiplier.

The re-use rate is a measure used by Bottazzi, Luque, and Páscoa (2012) and is defined as the ratio of the market value of the re-used securities to the overall market activity. The re-use rate $(r r)$ is an arbitrary value in the interval $[0,1)$, where a value of zero would imply no re-use at all and a value arbitrarily close to one would imply an almost infinite re-use. Hence, the re-use rate is a relative measure of the re-use activity in a repo market. This measure can be applied to the overall market as well as to individual institutions. The re-use rate at time $t$ is defined as follows:

$$
r r_{t}=\frac{\sum_{n=1}^{N} d_{n} c_{n, t}}{\sum_{n=1}^{N} c_{n, t}}
$$


where $c_{n, t}$ denotes the value of collateral $n$ of an outstanding repo at time $t$. To account for the re-use of collateral, a dummy variable $d_{n}$ is included, which is equal to one if the collateral is re-used and zero otherwise.

The re-use rate, however, does not consider the overall pool of eligible securities and therefore does not give an indication of the impact of the re-use on the overall pool. To account for the availability of securities, the collateral multiplier can be adopted from its famous pendant, the money multiplier. For this paper, we define the collateral multiplier $(m)$ as 1 plus the ratio of re-used collateral divided by the available pool of securities. It is thus an arbitrary value in the interval $[1, \infty)$ and defined as follows:

$$
m_{t}=1+\frac{\sum_{n=1}^{N} d_{n} c_{n, t}}{\sum_{i=1}^{I} s_{i, t}}
$$

where $s_{i, t}$ is the market value of the available securities $(i)$ eligible for repos at time $t$ (i.e. securities available from the SNB GC basket). For example, a re-use of securities worth CHF 5 bn and a pool of eligible securities amounting to CHF 10 bn would imply a collateral multiplier of 1.5. The collateral multiplier thus links the re-use to the overall availability of securities, whereas the re-use rate is a measure of the frequency of collateral re-use within the overall market.

\subsection{Re-use rate and collateral multiplier over time}

Figures 2 and 3 show the development of the re-use rate and collateral multiplier over time. On average, the re-use rate was about 0.05 . In other words, $5 \%$ of the outstanding volume was secured with re-used collateral. Figure 2 reveals that the re-use rate remained relatively constant until mid-2007, at about 0.075 to 0.125 . Afterwards, it increased and reached its highest value in autumn 2007, at about 0.2 . In 2008 , the re-use rate suddenly declined to a level of roughly 0.02 and remained unchanged afterwards.

The collateral multiplier shows a similar pattern (see table 1). The collateral multiplier also spiked in autumn 2007, especially when the available collateral suddenly dropped. It reached its maximum value of almost 1.2 in the third quarter of 2007 indicating a relative shortage of collateral. Afterwards, the collateral multiplier shows a similar picture as the re-use rate, even though the available pool of collateral decreased remarkably in 2011.

The re-use of collateral reached its highest value in 2007, i.e. before the outstanding volume of the CHF repo market peaked and prior to the outbreak of the financial crisis. During this period, the banks' pool of available securities decreased twice (see figure 3). Therefore, the increasing re-use activity might have been due to collateral constraints of certain banks that were consequently forced to re-use collateral.

Finally, it is worth mentioning that the re-use activity remained very low after 2009, even though the pool of available securities declined to its lowest level in the observation period. This might be due to the very low trading activity or also due to a structural change in the market. Prior to 2009, market participants acting as cash provider and cash taker were prevalent. After 
the financial crisis, this share dropped significantly. For example, in August 2011, only $74 \%$ of the outstanding volume was due to market participants who had outstanding volume as cash taker and provider, whereas this share was about $97 \%$ prior to 2009.

\section{Determinants of re-use}

In the following we evaluate the determinants of collateral re-use. The re-use can be seen as a binary decision: either a collateral transaction is covered with a re-used security or not. Thus, we estimate a binary response model. We therefore analyse by what factors the re-use of collateral is influenced and not how much in value is re-used. ${ }^{10}$ In the following subsections, we motivate our hypotheses, describe the modifications to the dataset, specify our regression model and discuss the regression results.

\subsection{Hypotheses}

Without re-use of collateral, the market activity in the CHF repo market is constrained by the pool of available securities. The re-use of collateral reduces this constraint. In other words, a reduction in the availability of securities will ceteris paribus require the re-use of collateral to increase, given a specific outstanding volume. Levels and Capel (2012) thus argue that the re-use of collateral is a special form of collateral optimisation. Hence, we expect an increasing pool of available securities to have a negative impact on the re-use activity. The availability of securities is measured by the market value of all available (SNB eligible) securities, reported on a quarterly basis by FINMA regulated banks (i.e. banks domiciled in Switzerland).

Hypothesis 1: An increasing pool of available securities reduces the probability of a re-use.

The re-use activity in the interbank market might also be determined by the securities borrowing activity of banks from clients' accounts (SNB eligible and non-SNB eligible). ${ }^{11}$ Hence, we include securities borrowing from clients' accounts in the analysis. We expect the re-use of collateral to increase if the securities borrowing activity increases (i.e. securities borrowing is a complement). In other words, banks simultaneously re-use collateral and borrow securities from clients' accounts in times of high scarcity of collateral. Note that securities borrowing is also determined by the pool of available securities. We consider this fact in the regression analysis by orthogonalising the securities borrowing variable (see next section).

Hypothesis 2: The re-use of collateral increases with the securities borrowing activity.

\footnotetext{
${ }^{10}$ The value of a collateral transaction depends on the face value of the underlying security. Thus, a censored normal regression model would not be appropriate to model the decision to re-use collateral.

${ }^{11}$ In 2009, FINMA introduced a new legislation concerning SLB transactions, which resulted in a significant decline of securities borrowing from clients' accounts (see table 1).
} 
Monnet (2011) argues that "rehypothecation lowers traders' funding liquidity needs [or stress], the ease with which a trader can obtain funding". This argument also applies for the re-use of collateral. In interbank repo markets banks often lend cash long-term and refinance themselves short-term. Re-using collateral in those transactions would reduce bank's collateral needs (the own securities used) and thereby increase overall market liquidity (Brunnermeier and Pedersen, 2009). Accordingly, the re-use of collateral is especially valuable for banks in short-term refinancing operations. Put differently, the re-use of collateral facilitates playing the yield curve and allows banks to keep their pool of own securities relatively small, which reduces transaction costs. To empirically test this hypothesis, we include the share of outstanding long-term transactions (i.e. with a term longer than one month) as well as the duration of the transaction as independent variables. On the one hand, we expect a positive relationship between the share of outstanding long-term transactions and the probability of re-use. On the other hand, the re-use probability is expected to be higher if the duration of a repo transaction is shorter.

Hypothesis 3: The re-use of collateral is especially popular for banks when lending cash longterm and borrowing cash short-term.

Singh and Aitken (2010) show that rehypothecation has significantly decreased with the intensification of the financial crisis, as market participants became more and more risk-averse. If market participants in the CHF repo market were to associate risk with the re-use of collateral, one could expect a negative relation between stress in the CHF money market and the re-use of collateral. To account for money market stress, the credit risk premium, measured by the spread between the unsecured and the secured interest rate for CHF liquidity in the tom-next maturity (TOIS-fixing minus SARTN) is included in the analysis.

Hypothesis 4: The re-use activity decreases with money market stress.

Empirical and theoretical research has shown that the relationship between two market participants significantly impacts trading conditions (see for example Furfine (1990)). Recently, Duffie (2013) presented evidence that during the financial crisis prime-brokerage clients (collateral providers) made sure that the securities they held in their custodies were not rehypothecated by their broker-dealers. Theoretical models by Infante (2014) and Eren (2014) predict this behaviour and show that a collateral provider might have an incentive to withdraw its securities during crisis periods. Based on these models, one might also expect that the relationship between two market participants in the CHF repo market influences the re-use of collateral. Collateral providers that re-use collateral might be concerned about not receiving back the collateral which they have to return to the initial collateral provider. This risk amplifies with a weak diversification of the re-using counterparty. In the regression we thus control for the diversification of the collateral provider, which is measured by the sum of cash taking transactions with the corresponding cash provider to the total sum of cash taker transactions. 
Thus, the measure for relationship is a value in the interval $(0,1]$. A very low value characterises a relatively low exposure to this counterparty whereas a value close to one indicates a very large exposure. We expect a high relationship ratio to reduce the probability of a re-use of collateral.

Hypothesis 5: Weakly diversified collateral providers re-use less collateral than well diversified collateral providers.

\subsection{Control variables}

As the CHF repo market is set up as a market with bilateral trade relationships, counterparties might also negotiate about the specific collateral delivered. According to Ewerhart and Tapking (2008), counterparties in bilateral markets prefer to use high-quality collateral in the interbank market and use it first in order to balance the counterparties' risk exposure as efficiently as possible. Therefore, they might have an incentive to deliver, and especially to re-use, good rather than bad collateral. Consequently, the credit rating of the corresponding security is taken into account. ${ }^{12}$

As Swiss banks have to fulfil minimum reserve requirements, one might expect that they also re-use collateral to fulfil these requirements (at least in the short run, just prior to the end of the maintenance period). Thus, we control for the individual liquidity position of market participants by including the daily gross excess reserve of a bank in analogy to Fecht, Nyborg, and Rocholl (2011).

Furthermore, we account for the overall outstanding volume in the CHF repo market. A higher outstanding volume might imply an increasing need for collateral re-use. Moreover, the re-use of securities might be conducted by market makers who are active as cash taker and cash provider in the same maturities on the same day. We therefore include a dummy variable indicating whether a market maker was involved in the transaction.

\subsection{Data}

For the binary response model below, the dataset is adjusted as follows. To exclude the period with very high excess liquidity and very low trading activity, we reduce the sample to the time period between 1 June 2006 and 2 August $2011^{13}$ reducing the number of collateral transactions to 426,042 . Further, only transactions, where the cash taker has outstanding cash provider repos at the same time are involved, as those participants are the only ones, which are able to re-use collateral. This shrinks the sample to 237,094 transactions. Additionally, 852 transactions are excluded due to missing observations in the money market stress variable. ${ }^{14}$ Finally, 2,242

\footnotetext{
${ }^{12}$ We consider the best security credit rating from Standard \& Poor's, Moody's or Fitch.

${ }^{13}$ On 3 August 2011 the SNB increased the supply of liquidity as a measure against strong CHF. Consequently, the trading activity decreased significantly.

${ }^{14}$ On the following days the SARTN rate was not available: 29 December 2006, 27 December 2007,31 December 2008 and 28 October 2009.
} 
transactions of banks, which do not exhibit a re-use of collateral are not considered in the dataset. Consequently, the final dataset contains 234,000 transactions.

Table 4: Descriptive statistics

\begin{tabular}{lrrrrrr}
\hline \hline Variable name & Unit & Mean & Std. dev. & Std. err. & Min. & Max. \\
\hline & & & & & & \\
Collateral re-use & dummy & 0.36 & 0.48 & 0.0010 & 0.00 & 1.00 \\
$\ln$ (Securities borrowing) & $\ln (\mathrm{bn})$ & 5.19 & 0.51 & 0.0011 & 4.11 & 5.65 \\
$\ln$ (Available securities) & $\ln (\mathrm{bn})$ & 4.29 & 0.24 & 0.0005 & 3.88 & 4.77 \\
Stress in money market & $\mathrm{pp}$ & 0.15 & 0.40 & 0.0008 & -0.09 & 3.28 \\
Relationship ratio & $\%$ & 11.25 & 16.56 & 0.0342 & 0.00 & 100.00 \\
Share long-term transactions & $\%$ & 63.01 & 10.19 & 0.0211 & 20.10 & 82.57 \\
Duration of transaction & days & 8.78 & 24.22 & 0.0501 & 1.00 & 370.00 \\
Rating AAA & dummy & 0.61 & 0.49 & 0.0010 & 0.00 & 1.00 \\
Rating AA+ & dummy & 0.08 & 0.28 & 0.0006 & 0.00 & 1.00 \\
Rating AA & dummy & 0.06 & 0.24 & 0.0005 & 0.00 & 1.00 \\
Rating AA- & dummy & 0.04 & 0.19 & 0.0004 & 0.00 & 1.00 \\
Rating A+ & dummy & 0.02 & 0.14 & 0.0003 & 0.00 & 1.00 \\
Rating A & dummy & 0.01 & 0.10 & 0.0002 & 0.00 & 1.00 \\
No rating & dummy & 0.18 & 0.38 & 0.0008 & 0.00 & 1.00 \\
Gross excess reserves & bn & 1.91 & 5.13 & 0.0106 & -2.68 & 303.94 \\
Market maker & dummy & 0.20 & 0.40 & 0.0008 & 0.00 & 1.00 \\
$\ln$ (Outstanding volume) & $\ln (\mathrm{bn})$ & 3.70 & 0.23 & 0.0005 & 2.73 & 4.28 \\
$\ln$ (Volume of transaction) & $\ln (\mathrm{mn})$ & 2.225 & 1.64 & 0.0034 & -15.53 & 6.02 \\
\hline \hline
\end{tabular}

Number of observations 234,000

The descriptive statistics of the variables can be found in table 4 . Overall, in $36 \%$ of the collateral transactions a re-use of collateral is observed. This probability is higher than indicated by the re-use rate due to two reasons. First, the dataset includes only transactions where the cash taker also has an outstanding volume as cash provider. Second, short-term transactions do not contribute as strongly to the re-use rate as longer-term transactions do. For variables in cash amounts we employ the natural $\log$, if they are strictly positive. For variables with observation frequencies lower than daily, the last available observation is used.

Table 10 in the appendix shows the correlation matrix of all independent variables. As we claim in hypothesis 1 , the securities borrowing variable is closely related to the available securities variable. The correlation coefficient between these two variables is -0.85 . To avoid a potential multicollinearity problem in our regression analysis we orthogonalise the securities borrowing variable (see equation 3 and table 9 for abbreviations) with respect to the available securities variable. The orthogonalised variable $(\eta)$ is denoted as securities borrowing (orth.). The correlation between the securities borrowing (orth.) and the original securities borrowing variable is 0.53 , showing that the orthogonalised variable qualifies as a valid measure for securities borrowing.

$$
S B_{i}=\beta_{1}+\beta_{2} A P_{i}+\eta_{i}
$$




\subsection{Binary response model}

To determine the re-use of collateral, we use a logit model with clustered standard errors. ${ }^{15}$ We regress the dummy variable collateral re-use (indicating whether a security has been re-used or not) on the variables specified above. Equation 4 and 5 show our regression specifications (see table 9 for abbreviations).

$$
\begin{gathered}
\operatorname{Pr}\left[y_{i}=1 \mid \boldsymbol{x}_{i}\right]=\frac{\exp \left(\boldsymbol{x}_{i}^{\prime} \boldsymbol{\theta}\right)}{1+\exp \left(\boldsymbol{x}_{i}^{\prime} \boldsymbol{\theta}\right)} \\
\boldsymbol{x}_{i}^{\prime} \boldsymbol{\theta}=\beta_{1}+\beta_{2} S B_{i}+\beta_{3} A P_{i}+\beta_{4} R E_{i}+\sum_{j=1}^{J-1} \delta_{j} R A_{i}+\beta_{5} M S_{i}+\beta_{6} G E_{i} \\
+\beta_{7} M M_{i}+\beta_{8} O V_{i}+\beta_{9} D U_{i}+\beta_{10} V A_{i}+\beta_{11} L T_{i}+\sum_{n=1}^{N-1} \gamma_{n} d_{i, n}
\end{gathered}
$$

$R A_{i, j} \quad$ dummy variable $=1$ if credit rating $j$ was used in transaction $i$, else $0 . J$ represents the credit rating categories $\mathrm{AAA}, \mathrm{AA}+, \mathrm{AA}, \mathrm{AA}-, \mathrm{A}+, \mathrm{A}$ and no credit rating;

$d_{i, n} \quad$ dummy variable $=1$ if bank $n$ was involved in transaction $i$, else 0.

We control for bank-specific effects by using dummy variables for $N-1$ cash takers. ${ }^{16}$ Since for a few small market participants there are only periodical observations, we pool small banks into one category. Those institutions, which were pooled into one category, account for less than $5 \%$ of the total turnover in the CHF repo market. Overall, 50 bank-specific dummy variables were included in the regression.

To account for potential intra-class correlation, we use clustered standard errors. Some regressors are variables with a daily, monthly or quarterly frequency. Consequently, transactions e.g. settled on the same trading day exhibit the same values for some of the independent variables. Thus, the regression residuals of these observations might be serially correlated. As most of our independent variables have at least a daily observation frequency, we use standard errors clustered by trading day in the baseline regression. Another possibility would be to use standard errors clustered by cash taker. As we control for individual heterogeneity by including bank-specific dummy variables, clustering by trading day is preferred to clustering by cash taker.

\footnotetext{
${ }^{15}$ Standard probit and logit models show similar measures of goodness of fit (pseudo $R^{2}$ of about 0.19 ). To compare the two models, the fitted log-likelihoods are calculated (Cameron and Trivedi, 2005). Since the fitted log-likelihood of the logit model slightly outperforms the probit model, we focus on the logit model.

${ }^{16}$ Note that the dataset, containing a fixed number of participants and a large number of observations allows us to run an unconditional logit regression instead of a conditional logit regression (Cameron and Trivedi, 2005).
} 
Table 5: Logit regression results

The coefficients of a logit regression represent the log of the odds ratios. The predicted re-use probabilities for different variables are given in figure 6 . The sample period lasts from June 2006 - August 2011. For variables in cash amounts we employ the natural log if they are $\gg 0$. Bank-specific dummy variables are not reported. Standard errors are clustered by trading day. The securities borrowing (orth.) variable is orthogonalised as specified in equation 3 .

\begin{tabular}{|c|c|c|}
\hline Collateral re-use (dummy) & Coeff. & Std. err. \\
\hline \multicolumn{3}{|l|}{ Scarcity of collateral } \\
\hline $\ln$ (Securities borrowing) (orth.) & $0.462^{* * *}$ & 0.0657 \\
\hline $\ln ($ Available securities (bn CHF) & $-0.652^{* * *}$ & 0.1100 \\
\hline Stress in money market (pp) & -0.0539 & 0.0759 \\
\hline Relationship ratio (\%) & $-0.00735^{* * *}$ & 0.0009 \\
\hline \multicolumn{3}{|l|}{ Maturity of transactions } \\
\hline Share long-term transactions (\%) & $0.0143^{* * *}$ & 0.0023 \\
\hline Duration of transaction (days) & $-0.0245^{* * *}$ & 0.0012 \\
\hline \multicolumn{3}{|l|}{ Control variables } \\
\hline Rating AA+ (dummy) & $0.363^{* * *}$ & 0.0264 \\
\hline Rating AA (dummy) & $-0.0538^{*}$ & 0.0263 \\
\hline Rating AA- (dummy) & -0.0439 & 0.0356 \\
\hline Rating $\mathrm{A}+$ (dummy) & $0.295^{* * *}$ & 0.0431 \\
\hline Rating A (dummy) & 0.0708 & 0.0618 \\
\hline No rating (dummy) & $-0.952^{* * *}$ & 0.0310 \\
\hline Gross excess reserves (bn CHF) & -0.0038 & 0.0032 \\
\hline Market maker (dummy) & -0.0107 & 0.0423 \\
\hline $\ln ($ Outstanding volume (bn CHF)) & $0.859^{* * *}$ & 0.0915 \\
\hline $\ln ($ Volume of transaction $(\mathrm{mn} \mathrm{CHF}))$ & 0.0097 & 0.0076 \\
\hline Constant & $-2.076^{* *}$ & 0.7510 \\
\hline
\end{tabular}

Number of observations: 234,000

Pseudo $R^{2}$ : 0.19

Log-likelihood: $-124,242.6$

Log-likelihood (0): $-153,159.2$

${ }^{*} \mathrm{p}<5 \%,{ }^{* *} \mathrm{p}<1 \%,{ }^{* * *} \mathrm{p}<0.1 \%$ 


\subsection{Regression results}

The regression results are illustrated in table 5. The log-likelihood of the null-model is significantly lower than the estimated model indicating an overall significant regression. The coefficients of a logit regression represent the log of the odds ratios. Interpretations in the following focus on the sign and the significance of the coefficients, which determine the direction of the corresponding marginal effect. The majority of the coefficients are significant at least at the $5 \%$ significance level including most of the coefficients for the bank-specific effects.

We find a significant and negative effect of the availability of securities (i.e. pool of available securities) on the re-use probability. This implies that market participants tend to re-use in times when the availability of securities is low. Shocks in the collateral universe are thus (at least partially) absorbed by an increasing re-use activity. A shortage of available securities does consequently increase the re-use activity. The re-use of collateral therefore supports market activity in the CHF repo market, especially when available securities become scarce. This evidence supports hypothesis 1 discussed in the previous subsection.

Furthermore, the coefficient for securities borrowing (orth.) is positive and significant. The fewer securities borrowed from customers, the lower is the probability of collateral re-use. This clearly indicates that banks re-use collateral when they also borrow securities from client accounts - i.e. re-use and securities borrowing are indeed complements (hypothesis 2).

The coefficients for the duration of the transaction and the share of long-term transactions are statistically significant and confirm hypothesis 3 . The longer the duration of a transaction, the lower the probability for collateral re-use. Furthermore, the regression results show that collateral re-use does occur more often when the share of long-term repos in the market is high. Consequently, our findings support the hypothesis that the re-use of collateral is used to lend cash long-term and to borrow cash short-term. Re-use might thus enhance trading activity and reduce traders funding liquidity needs as proposed by Monnet (2011).

The coefficients for the relationship ratio indicate a negative impact of a weak diversification of the collateral provider on the re-use probability. Hence, if the re-using counterparty only borrows cash (lends collateral) from a few cash providers (i.e. the relationship ratio is high), it is more careful about re-using collateral. This supports hypothesis 5 that re-using intermediaries might be worried about not receiving back their collateral, which they have to return to the initial collateral provider. However, the money market stress variable does not exhibit statistically significant coefficients. This might be due to the fact that the re-use of collateral is only observable for the re-using counterparty and not for the initial collateral provider. We therefore cannot confirm that money market stress has a negative impact on the re-use of collateral. Thus, we find no evidence supporting hypothesis 4 .

The coefficients of the control variables are partly significant and show the expected signs. The overall market activity (i.e. the outstanding volume) positively affects the re-use probability. The coefficients for the credit ratings show that especially the re-use probability for securities with no credit rating is reduced compared to the reference category (AAA-rating). 


\subsection{Predictions}

The logit model is a non-linear model and therefore the coefficients cannot be interpreted as semi-elasticities (Winkelmann and Boes, 2006). We therefore calculate predicted re-use probabilities (conditional probabilities) for different levels of one independent variable, with all other variables held constant (see figure 6).

The increase in the re-use probability tends to be non-linear especially for the duration of a transaction. The re-use probability decreases sharply with an increasing duration of the transaction. Whereas the re-use probability is around $40 \%$ in overnight transactions, it decreases to almost zero in transactions with a duration of more than 200 days. Moreover, also the securities borrowed (orth.) and available securities variables have a strong and non-linear impact on the re-use probability. For example, the predictions show that the re-use probability decreases from $41 \%$ to $31 \%$ when the pool of available securities increases from 50 to $100 \mathrm{bn}$.

Furthermore, the outstanding volume exhibits a strong positive effect on the re-use probability. Since the scarcity of collateral ceteris paribus also increases in the outstanding interbank volume, the positive relationship further supports the hypothesis that the re-use of collateral is increasing in the scarcity of collateral.

Figure 5 shows the predicted re-use probabilities conditional on different credit rating categories. The figure reveals that the re-use activity also depends on the credit rating of the collateral. Especially, securities without credit rating (e.g. short-term government debt) are re-used less frequently.

\subsection{Robustness}

In order to check the robustness of our findings we run several additional regressions. First, we cluster standard errors by date, month and quarter (see table 6). Consequently, some of the coefficients lose statistical power. However, all coefficients remain significant at least on a $5 \%$ level except the constant. Second, we check the robustness with respect to the scarcity of collateral variables (i.e. securities borrowing and available securities). Table 7 reports the baseline regression results as well as the regression results when dropping one of the two variables. In both cases, the remaining collateral availability variable persists to be significant with its corresponding sign, whereas other variables change only marginally. Finally, we also run a regression without bank-specific dummy variables (see table 8). Even though we neglect individual heterogeneity in this case, the model performs relatively well and most of the coefficients keep their sign and significance. The only exception is the money market stress variable which becomes negative and significant at the $5 \%$ level.

\section{Concluding remarks}

This paper sheds light on the re-use of collateral in an interbank repo market. By developing and applying an algorithm on transaction data from the CHF repo market, we are not only 
able to document the re-use activity, but also identify the drivers of collateral re-use before, during and after the financial crisis.

Our estimations show that on average the re-use rate was at about $10 \%$ prior to the financial crisis. With the reduction of available collateral just before the outbreak of the crisis, the reuse rate reached its maximum of almost $20 \%$, but declined significantly in the third quarter of 2008 and has not recovered yet. The results complete recent findings by Singh (2011) as well as Aitken and Singh (2009) in at least two important areas. First, we confirm by using actual transaction data that the re-use activity substantially declined after the financial crisis. Second, we show that the re-use within the interbank repo market can significantly differ from the level of rehypothecation.

The regression analysis provides evidence that the re-use activity depends on the availability of collateral. Market participants tend to re-use when the collateral scarcity increases and in times when they also borrow a lot of securities from their client's. Further, we find evidence for a significant impact of the maturity of the transaction on the re-use probability. The longer the duration of a transaction, the lower the probability for a collateral re-use.

With the methodology and the data at hand, future research on the re-use of collateral can be done. In particular, it might be worth investigating in the cross-currency and the cross-instrument re-use of collateral as well as the re-use activity of individual banks. 


\section{References}

Aitken, J., and M. Singh. 2009. Deleveraging After Lehman - Evidence from Reduced Rehypothecation. IMF Working Paper 09/42.

Bank of England. 2012. The Framework for the Bank of England's Operations in the Sterling Money Markets. Updated June 2012.

Bindseil, U., K. Nyborg, and I. Strebulaev. 2009. Repo auctions and the market for liquidity. Journal of Money, Credit and Banking 41:1391-1421.

Bottazzi, J.-M., J. Luque, and M. Páscoa. 2012. Securities Market Theory: Possession, Repo and Rehypothecation. Journal of Economic Theory 147:477-500.

Brunnermeier, M., and L. Pedersen. 2009. Market Liquidity and Funding Liquidity. Review of Financial Studies 22:2201-2238.

Cameron, C., and P. Trivedi. 2005. Microeconometrics: Methods and Applications. Cambridge University Press.

Committee on the Global Financial System. 2013. Asset Encumbrance, Financial Reform and the Demand for Collateral Assets. CGFS Papers No. 49.

Copeland, A., A. Martin, and M. Walker. 2011. Repo Runs: Evidence from the Tri-Party Repo Market. New York Federal Reserve Bank Staff Report 506.

Duffie, D. 2013. Replumbing our financial system: uneven progress. International Journal of Central Banking 9:251-279.

Eren, E. 2014. Intermediary Funding Liquidity and Rehypothecation as Determinants of Repo Haircuts and Interest Rates. Available at SSRN No. 2459352.

Ewerhart, C., and J. Tapking. 2008. Repo Markets, Counterparty Risk, and the 2007-2009 Liquidity Crisis. ECB Working Paper No. 909.

Fecht, F., K. Nyborg, and J. Rocholl. 2011. The Price of Liquidity: The Effects of Market Conditions and Bank Characteristics. Journal of Financial Economics 102:344-362.

Financial Stability Board. 2012a. Securities Lending and Repos: Market Overview and Financial Stability Issues. Interim Report of the FSB Workstream on Securities Lending and Repos.

Financial Stability Board. 2012b. Strengthening Oversight and Regulation of Shadow Banking. A Policy Framework for Addressing Shadow Banking Risks in Securities Lending and Repos.

Furfine, C. 1990. The Pricing of Bank Lending and Borrowing: Evidence from the Federal Funds Market. BIS Working Paper No. 62. 
Gorton, G., and A. Metrick. 2010a. Haircuts. Federal Reserve Bank of St. Louis Review 2010:261-297.

Gorton, G., and A. Metrick. 2010b. Regulating the Shadow Banking System. Brookings Papers on Economic Activity pp. 261-297.

Gorton, G., and A. Metrick. 2012. Securitized Banking and the Run on Repo. Journal of Financial Economics 104:425-451.

Guggenheim, B., S. Kraenzlin, and S. Schumacher. 2011. Exploring an Uncharted Market: Evidence on the Unsecured Swiss Franc Money Market. Aussenwirtschaft 66.

He, Z., and W. Xiong. 2012. Dynamic Debt Runs. Review of Financial Studies 25:1799-1843.

Hördahl, P., and M. King. 2008. Developments in Repo Markets During the Financial Turmoil. BIS Quarterly Review December 2008.

Infante, S. 2014. Money for nothing: The consequences of repo rehypothecation. Available at SSRN No. 2460979.

Kraenzlin, S. 2007. The characteristics and development of the Swiss franc repurchase agreement market. Financial Markets and Portfolio Management 21:241-261.

Kraenzlin, S., and T. Nellen. 2014. Access policy and money market segmentation. Journal of Monetary Economics forthcoming.

Kraenzlin, S., and B. von Scarpatetti. 2011. Bargaining Power in the Repo Market. SNB Working Paper No. 2011-14.

Levels, A., and J. Capel. 2012. Is Collateral Becoming Scarce? Evidence for the Euro Area. The Journal of Financial Market Infrastructures 1:29-53.

Mancini, L., A. Ranaldo, and J. Wrampelmeyer. 2013. The Euro Interbank Repo Market University of St. Gallen Working Paper No. 2013/16.

Monnet, C. 2011. Rehypothecation. Business Review, Federal Reserve Bank of Philadelphia pp. $18-25$.

Singh, M. 2011. Velocity of Pledged Collateral: Analysis and Implications. IMF Working Paper No. 256.

Singh, M., and J. Aitken. 2010. The (Sizable) Role of Rehypothecation in the Shadow Banking System. IMF Working Paper No. 172.

SIX Securities Services. 2013. Service Guide SIX SIS Ltd, Repo.

Swiss Bankers Association. 1999. Schweizer Rahmenvertrag für Repo-Geschäfte, Bilaterale Version. 
Swiss National Bank. 2004. Guidelines of the Swiss National Bank on Monetary Policy Instruments. As at 1 January 2013.

Swiss National Bank. 2007. SNB to expand its list of collateral eligible at the central bank. Press release, 14 August 2007.

Swiss National Bank. 2008. Instruction Sheet on the Custody Cover Account "SNB". Appendix to the Guidelines of the Swiss National Bank (SNB) on Monetary Policy Instruments. As at 31 December 2008.

Swiss National Bank. 2010. Instruction sheet on cashless payment transactions. As at 1 June 2010.

Wechsler, R. 1999. Das Repo-Geschäft: eine Innovation am Schweizer Finanzmarkt: Aspekte der Verbuchung und Unterlegung von Repo-Geschäften. Schweizerische Bankiervereinigung.

Winkelmann, R., and S. Boes. 2006. Analysis of Microdata. Berlin: Springer Verlag. 


\section{A Appendix}

\section{A.1 Selection of collateral in SECOM}

The selection of securities for a repo transaction in SECOM can be done manually or automatically by the so-called 'GC select' algorithm. The majority of market participants use the automatic selection process. The GC select chooses securities from a predefined pool of available securities (SIX Securities Services, 2013). The pool of available securities (the so called 'release list') has to be maintained by the market participant. Besides other information included on the ISINs, the release list contains the corresponding quantity available, the date of the next coupon payment ('valid till date') and the date until the security is available for repos ('release till date', which is typically equal to the valid till date). Securities received in a repo are classified as 'purchased securities'. With the default setting, these securities are not shifted to the release list but to the so called 'non-release list'. Furthermore, the release till date of purchased securities is not equal to the valid till date as in the default setting, but equals the repurchase date of the initial transaction. However, market participants can change the default setting. Currently, two-thirds of all account owners adjust the default option such that purchased securities are automatically transferred to the release list. ${ }^{17}$ This means that they intend to re-use collateral. Other account owners - using the default setting - still have the option of transferring specific ISINs from the non-release list to the release list.

For a repo transaction, the GC select picks securities by using a predefined methodology. First, it selects securities from the collateral category defined, then it rejects securities that are not eligible (e.g. own banking group securities) and finally it removes all securities that have a valid till date prior to the repurchase date of the repo transaction (SIX Securities Services, 2013). From this remaining list, the GC select first chooses the securities with the shortest possible release till date (SIX Securities Services, 2013), thus preferring the securities that stem from another transaction.

\section{A.2 Re-use activity when relaxing the repurchase condition}

The algorithm identifies a transaction as a re-use transaction only if the repurchase date of the re-use transaction is not later than the repurchase date of the initial transaction. However, a re-use might also occur without satisfying this condition, since the collateral taker of the initial transactions only has to return the same ISIN at the repurchase date - but not the same security. In this case, the collateral taker needs to obtain the same collateral somewhere else (e.g. secondary market) in order to return the security to the initial owner.

Figure 4 shows the estimated re-use without the repurchase condition. It becomes clear that the re-use identified is about twice as large but has a very similar pattern. The re-use activity without repurchase condition can be seen as an upper limit of the possible re-use activity in the CHF repo market.

\footnotetext{
${ }^{17}$ Securities received from margin calls are transferred to the release list but flagged and are thus not available for the GC select.
} 


\section{A.3 Fungibility of ISINs and implications for the re-use}

The algorithm might overestimate the re-use of collateral, as we are only able to compare the ISINs but cannot guarantee that exactly the same security has been re-used. Securities of the same issuance cannot be distinguished from each other - i.e. they are perfectly fungible. In other words, a security - with the same ISIN as the purchased security in the repo transaction - could have already been on the release list and then used in the re-use transaction. The algorithm would identify this as a re-use. However, as the GC select first chooses collateral with the youngest release till date, and purchased securities automatically have an earlier release till date than the same ISIN in the account, we do not expect the overestimation to be significant. 
Table 7: Robustness check: collateral variables

The table shows the baseline regression results and the regression results when dropping one of the two scarcity of collateral variables. Model 1 is without the securities borrowing (orth.) variable and model 2 without the available securities variable. For variables in cash amounts we employ the natural log if they are $\gg 0$. Bank-specific dummy variables are not reported. Standard errors are clustered by trading day. The securities borrowing (orth.) variable is orthogonalised as specified in equation 3.

\begin{tabular}{|c|c|c|c|c|c|c|}
\hline \multirow[b]{2}{*}{ Collateral re-use (dummy) } & \multicolumn{2}{|c|}{ Baseline } & \multicolumn{2}{|c|}{ Model 1} & \multicolumn{2}{|c|}{ Model 2} \\
\hline & Coeff. & Std. err. & Coeff. & Std. err. & Coeff. & Std. err. \\
\hline \multicolumn{7}{|l|}{ Scarcity of collateral } \\
\hline $\ln$ (Securities borrowing) (orth.) & $0.462^{* * *}$ & 0.0657 & & & $0.353^{* * *}$ & 0.0644 \\
\hline $\ln$ (Available securities) & $-0.652^{* * *}$ & 0.1100 & $-0.457^{* * *}$ & 0.1090 & & \\
\hline Stress in money market (pp) & -0.0539 & 0.0759 & -0.104 & 0.0764 & -0.106 & 0.0747 \\
\hline Relationship ratio (\%) & $-0.00735 * * *$ & 0.0009 & $-0.00764 * * *$ & 0.0009 & $-0.00827^{* * *}$ & \\
\hline \multicolumn{7}{|l|}{ Maturity of transactions } \\
\hline Share long-term transactions (\%) & $0.0143 * * *$ & 0.0023 & $0.0161 * * *$ & 0.0024 & $0.0217^{* * *}$ & 0.0020 \\
\hline Duration of transaction (days) & $-0.0245^{* * *}$ & 0.0012 & $-0.0240 * * *$ & 0.0012 & $-0.0243^{* * *}$ & 0.0012 \\
\hline \multicolumn{7}{|l|}{ Quality of collateral } \\
\hline Rating $\mathrm{AA}+$ (dummy) & $0.363^{* * *}$ & 0.0264 & $0.360^{* * *}$ & 0.0265 & $0.343^{* * *}$ & 0.0265 \\
\hline Rating AA (dummy) & $-0.0538^{*}$ & 0.0263 & $-0.0570^{*}$ & 0.0262 & $-0.0615^{*}$ & 0.0263 \\
\hline Rating AA- (dummy) & -0.0439 & 0.0356 & -0.0326 & 0.0359 & -0.033 & 0.0359 \\
\hline Rating $\mathrm{A}+$ (dummy) & $0.295^{* * *}$ & 0.0431 & $0.312^{* * *}$ & 0.0435 & $0.311^{* * *}$ & 0.0430 \\
\hline Rating A (dummy) & 0.0708 & 0.0618 & 0.0746 & 0.0625 & 0.0694 & 0.0625 \\
\hline No rating (dummy) & $-0.952^{* * *}$ & 0.0310 & $-0.943^{* * *}$ & 0.0313 & $-0.938 * * *$ & 0.0315 \\
\hline \multicolumn{7}{|l|}{ Control variables } \\
\hline Gross excess reserves (bn $\mathrm{CHF}$ ) & -0.00382 & 0.0032 & $-0.00822 *$ & 0.0036 & $-0.00872^{*}$ & 0.0038 \\
\hline Market maker (dummy) & -0.0107 & 0.0423 & 0.0119 & 0.0421 & 0.00827 & 0.0421 \\
\hline $\ln$ (Outstanding volume market) & $0.859 * * *$ & 0.0915 & $1.073^{* * *}$ & 0.0894 & $0.994^{* * *}$ & 0.0858 \\
\hline $\ln$ (Volume of transactions) & 0.00974 & 0.0076 & 0.00492 & 0.0077 & 0.00517 & 0.0076 \\
\hline Constant & $-2.076^{* *}$ & 0.7510 & $-3.841^{* * *}$ & 0.7290 & $-5.856^{* * *}$ & 0.3680 \\
\hline Number of observations: & \multicolumn{2}{|c|}{234,000} & \multicolumn{2}{|c|}{234,000} & \multicolumn{2}{|c|}{234,000} \\
\hline Pseudo $R^{2}$ : & \multicolumn{2}{|c|}{0.188} & \multicolumn{2}{|c|}{0.187} & \multicolumn{2}{|c|}{0.187} \\
\hline Log-likelihood: & \multirow{2}{*}{\multicolumn{2}{|c|}{$\begin{array}{l}-124,242.6 \\
-153,159.2\end{array}$}} & \multirow{2}{*}{\multicolumn{2}{|c|}{$\begin{array}{l}-124,497.1 \\
-153,159.2\end{array}$}} & \multirow{2}{*}{\multicolumn{2}{|c|}{$\begin{array}{l}-124,445.2 \\
-1531592\end{array}$}} \\
\hline Log-likelihood (0): & & & & & & \\
\hline
\end{tabular}


Table 8: Robustness check: bank-specific dummy variables

The table shows the baseline regression results and the regression results when dropping bank-specific dummy variables. For variables in cash amounts we employ the natural log if they are $\gg 0$. Bank-specific dummy variables are not reported in the baseline regression. Standard errors are clustered by trading day. The securities borrowing (orth.) variable is orthogonalised as specified in equation 3.

\begin{tabular}{|c|c|c|c|c|}
\hline \multirow[b]{2}{*}{ Collateral re-use (dummy) } & \multicolumn{2}{|c|}{ Baseline } & \multicolumn{2}{|c|}{ Without bank dummies } \\
\hline & Coeff. & Std. err. & Coeff. & Std. err. \\
\hline \multicolumn{5}{|l|}{ Scarcity of collateral } \\
\hline $\ln$ (Securities borrowing) (orth.) & $0.462 * * *$ & 0.0657 & $0.551^{* * *}$ & 0.062 \\
\hline $\ln$ (Available securities) & $-0.652^{* * *}$ & 0.1100 & $-0.496 * * *$ & 0.0983 \\
\hline Stress in money market (pp) & -0.0539 & 0.0759 & $-0.161^{*}$ & 0.0671 \\
\hline Relationship ratio (\%) & $-0.00735 * * *$ & 0.0009 & $-0.00165^{*}$ & 0.000743 \\
\hline \multicolumn{5}{|l|}{ Maturity of transactions } \\
\hline Share long-term transactions (\%) & $0.0143^{* * *}$ & 0.0023 & $0.00841^{* * *}$ & 0.00215 \\
\hline Duration of transaction (days) & $-0.0245^{* * *}$ & 0.0012 & $-0.0302^{* * *}$ & 0.00138 \\
\hline \multicolumn{5}{|l|}{ Quality of collateral } \\
\hline Rating $\mathrm{AA}+$ (dummy) & $0.363^{* * *}$ & 0.0264 & $0.209^{* * *}$ & 0.025 \\
\hline Rating AA (dummy) & $-0.0538^{*}$ & 0.0263 & $-0.104^{* * *}$ & 0.0244 \\
\hline Rating AA- (dummy) & -0.0439 & 0.0356 & $-0.0926^{* *}$ & 0.0319 \\
\hline Rating $\mathrm{A}+$ (dummy) & $0.295^{* * *}$ & 0.0431 & $0.258^{* * *}$ & 0.0383 \\
\hline Rating A (dummy) & 0.0708 & 0.0618 & $0.140 * *$ & 0.0523 \\
\hline No rating (dummy) & $-0.952 * * *$ & 0.0310 & $-1.030^{* * *}$ & 0.0304 \\
\hline \multicolumn{5}{|l|}{ Control variables } \\
\hline Gross excess reserves (bn $\mathrm{CHF}$ ) & -0.00382 & 0.0032 & $-0.00822^{*}$ & 0.0036 \\
\hline Market maker (dummy) & -0.0107 & 0.0423 & -0.0373 & 0.0408 \\
\hline $\ln$ (Outstanding volume market) & $0.859^{* * *}$ & 0.0915 & $0.375^{* * *}$ & 0.094 \\
\hline $\ln$ (Volume of transactions) & 0.00974 & 0.0076 & $0.0170^{*}$ & 0.00664 \\
\hline Constant & $-2.076^{* *}$ & 0.7510 & -0.00661 & 0.691 \\
\hline Number of observations: & \multicolumn{2}{|c|}{234,000} & \multicolumn{2}{|c|}{234,000} \\
\hline Pseudo $R^{2}$ : & \multicolumn{2}{|c|}{0.188} & \multicolumn{2}{|c|}{0.062} \\
\hline Log-likelihood: & \multicolumn{2}{|c|}{$-124,242.6$} & \multicolumn{2}{|c|}{$-144,664.0$} \\
\hline Log-likelihood (0): & \multicolumn{2}{|c|}{$-153,159.2$} & \multicolumn{2}{|c|}{$-154,160.5$} \\
\hline
\end{tabular}


Table 9: Abbrevation of variables

* Frequency of variables: $\mathrm{t}=$ for each transaction, $\mathrm{d}=$ daily, $\mathrm{m}=$ monthly, $\mathrm{q}=$ quarterly.

** Aggregation of variables: $\mathrm{i}=$ individual, o = over all banks

\begin{tabular}{lrrr}
\hline \hline Variable name & Frequency* & Aggregation** $^{* *}$ & Abbrevation \\
\hline Collateral re-use & $\mathrm{t}$ & $\mathrm{i}$ & $\mathrm{Y}$ \\
$\ln$ (Securities borrowing) & $\mathrm{m}$ & $\mathrm{o}$ & $\mathrm{SB}$ \\
$\ln$ (Available securities) & $\mathrm{q}$ & $\mathrm{o}$ & $\mathrm{AP}$ \\
Stress in money market & $\mathrm{d}$ & $\mathrm{o}$ & $\mathrm{MS}$ \\
Relationship ratio & $\mathrm{d}$ & $\mathrm{i}$ & $\mathrm{RE}$ \\
Share long-term transactions & $\mathrm{d}$ & $\mathrm{o}$ & $\mathrm{LT}$ \\
Duration of transaction & $\mathrm{t}$ & $\mathrm{i}$ & $\mathrm{DU}$ \\
Rating AAA & $\mathrm{t}$ & $\mathrm{i}$ & $\mathrm{RA}$ \\
Rating AA+ & $\mathrm{t}$ & $\mathrm{i}$ & $\mathrm{RA}$ \\
Rating AA & $\mathrm{t}$ & $\mathrm{i}$ & $\mathrm{RA}$ \\
Rating AA- & $\mathrm{t}$ & $\mathrm{i}$ & $\mathrm{RA}$ \\
Rating A+ & $\mathrm{t}$ & $\mathrm{i}$ & $\mathrm{RA}$ \\
Rating A & $\mathrm{t}$ & $\mathrm{i}$ & $\mathrm{RA}$ \\
No rating & $\mathrm{t}$ & $\mathrm{i}$ & $\mathrm{RA}$ \\
Gross excess reserves & $\mathrm{d}$ & $\mathrm{i}$ & $\mathrm{GE}$ \\
Market maker & $\mathrm{d}$ & $\mathrm{i}$ & $\mathrm{MM}$ \\
$\ln$ (Outstanding volume) & $\mathrm{d}$ & $\mathrm{o}$ & $\mathrm{OV}$ \\
$\ln$ (Volume of transaction) & $\mathrm{t}$ & $\mathrm{i}$ & $\mathrm{VA}$ \\
\hline \hline
\end{tabular}




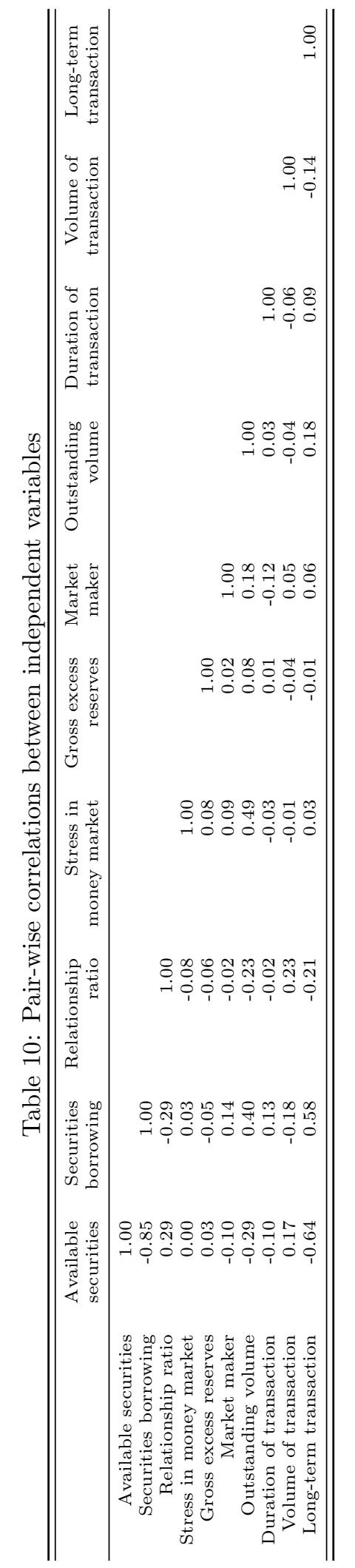




\section{A.5 Figures}

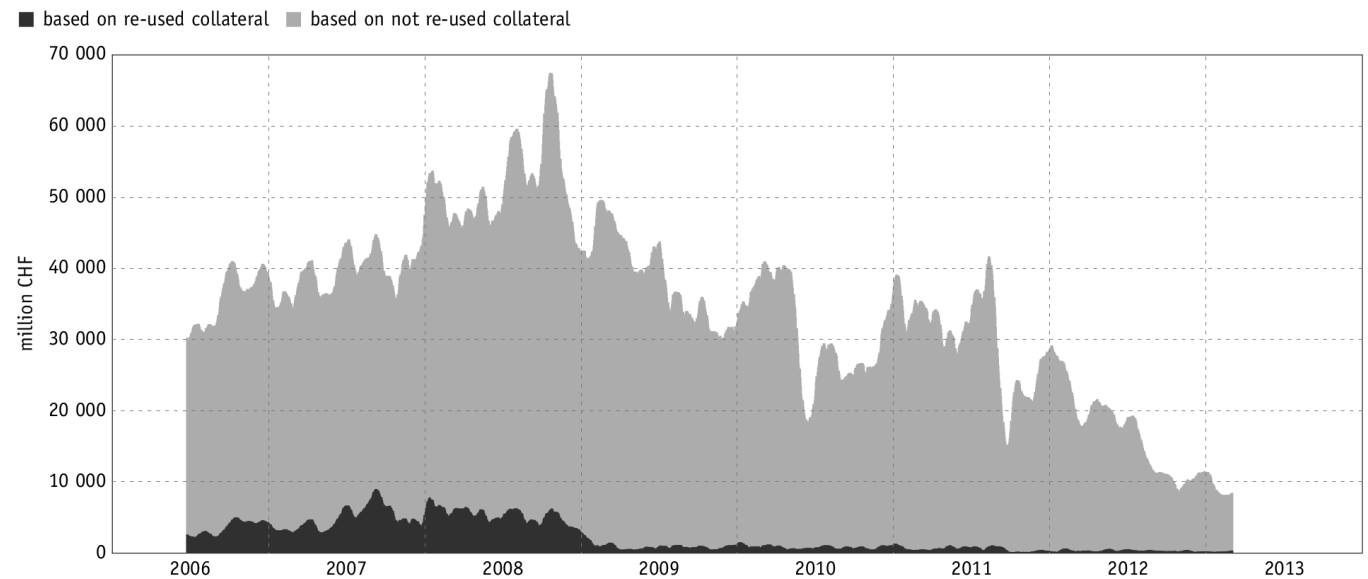

Figure 1: Outstanding volume

The dark grey area is based on re-used collateral, whereas the light grey area stacked on top corresponds to the outstanding volume without re-use (15 day moving average).

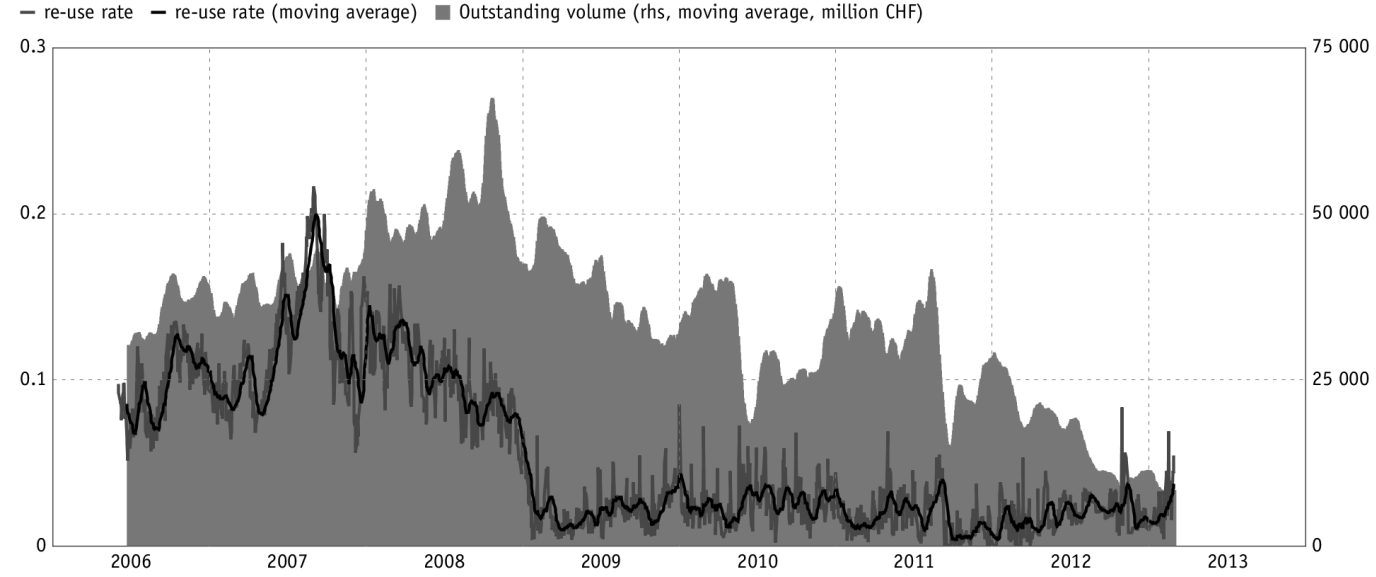

Figure 2: Re-use rate and outstanding volume

The grey area is the total outstanding volume in the CHF interbank repo market (15 day moving average). The light grey line is the daily re-use rate, whereas the black line is the re-use rate with a 15 day moving average. 


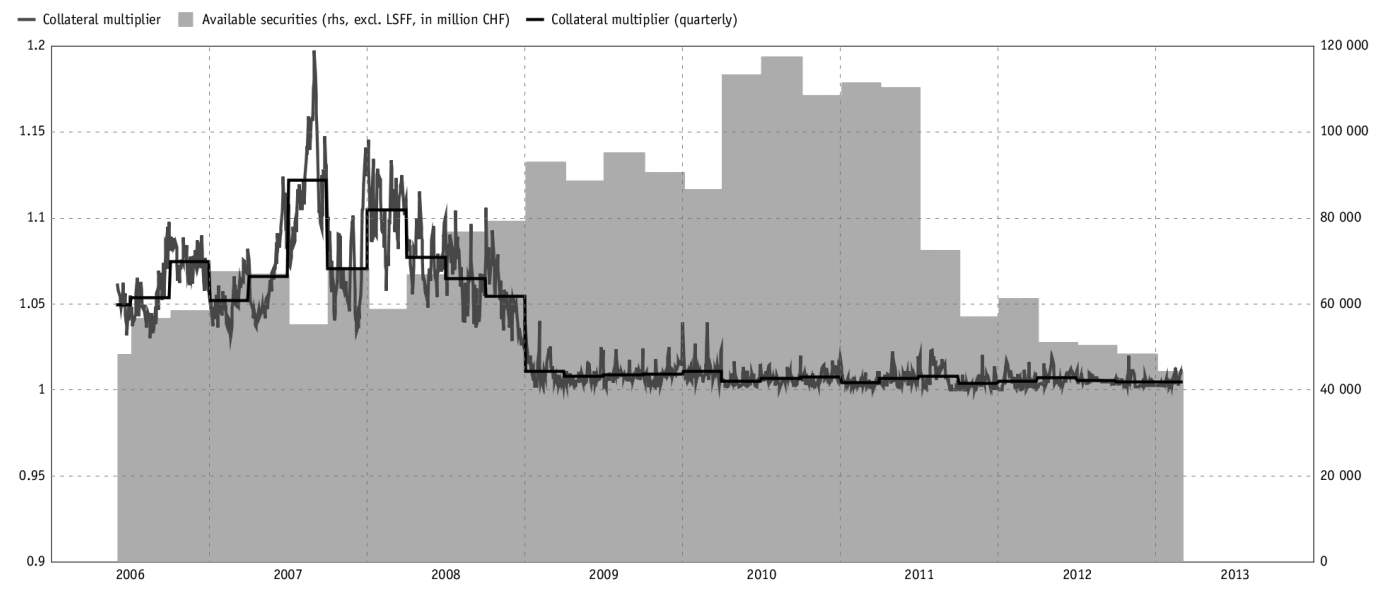

Figure 3: Collateral multiplier and available securities Available securities are SNB eligible securities minus the securities held in the custody cover account "SNB" for the liquidity-shortage financing facility. The light grey line is the daily collateral multiplier, whereas the black line is the collateral multiplier on a quarterly basis.

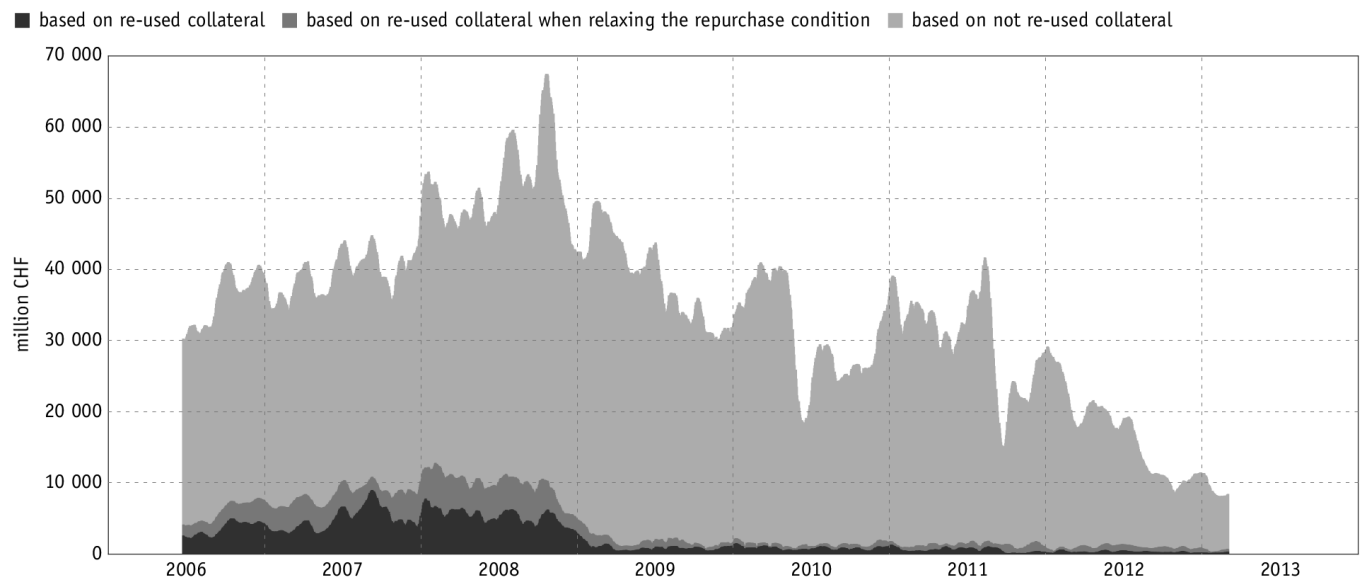

Figure 4: Outstanding volume when relaxing the repurchase condition

The black area is based on re-used collateral with repurchase condition. The dark grey area is based on re-used collateral when relaxing the repurchase condition, whereas the light grey area that is stacked on top corresponds to the outstanding volume without re-use condition (15 day moving average). 


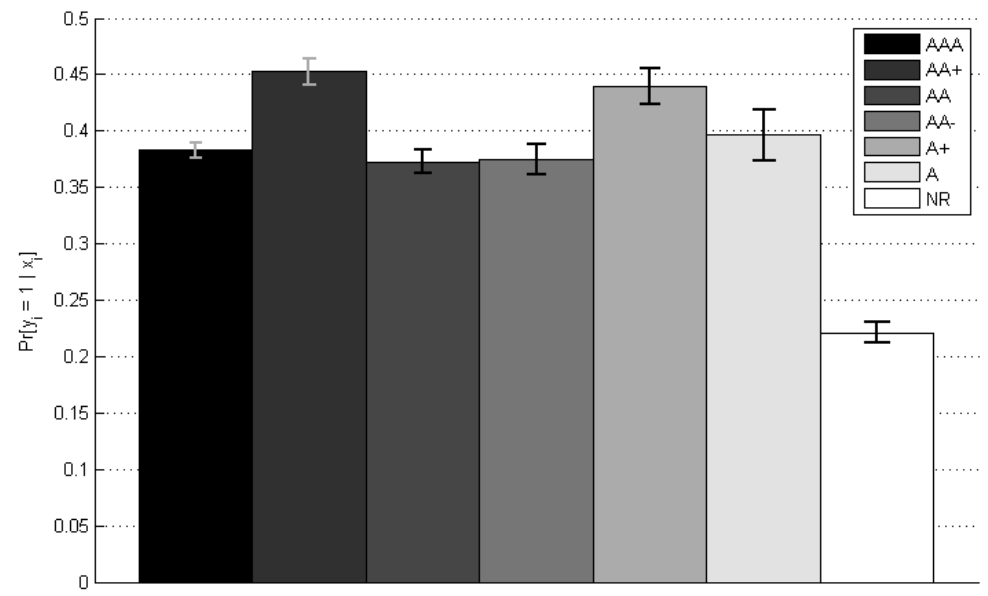

Figure 5: Predicted re-use probabilities for different rating categories

The vertical axis is the estimated probability of a re-use conditional on the rating category, with all other variables held constant. The predicted re-use probabilities are based on the regression coefficients. The vertical lines illustrate the corresponding $95 \%$ confidence intervals. Note that securities with a credit rating lower than AA- must be denominated in CHF. 

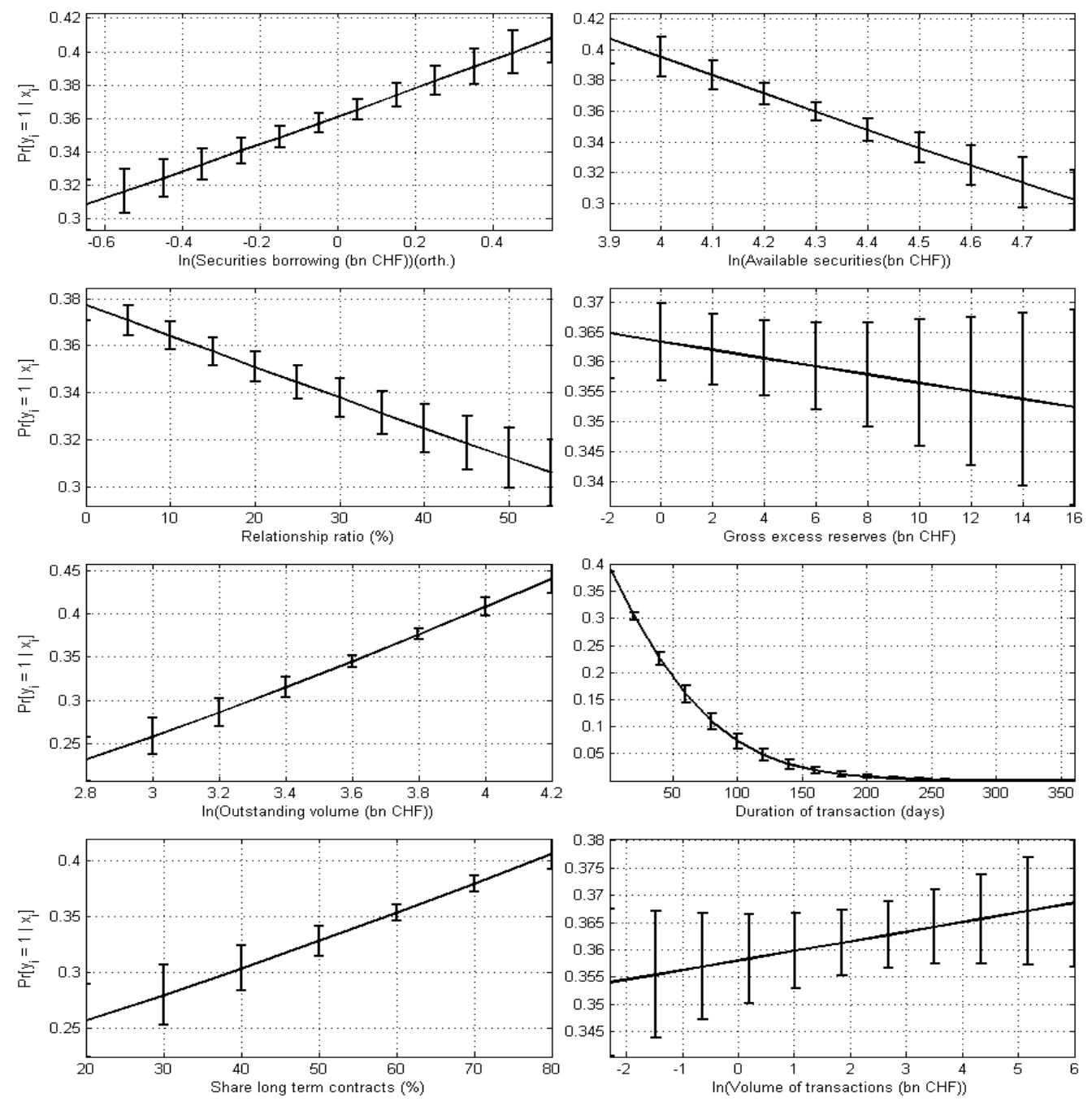

Figure 6: Predicted re-use probabilities for different levels of a variable

The vertical axis is the estimated probability of a re-use conditional on different levels of the explanatory variable, with all other variables held constant. The predicted re-use probabilities are based on the significant regression coefficients. The vertical lines illustrate the corresponding $95 \%$ confidence intervals. The predicted re-use probabilities need to be considered as hypothetical values, since certain values in certain periods simply did not exist, e.g. the gross excess reserves before the crisis never exhibited values as large as after the crisis. 


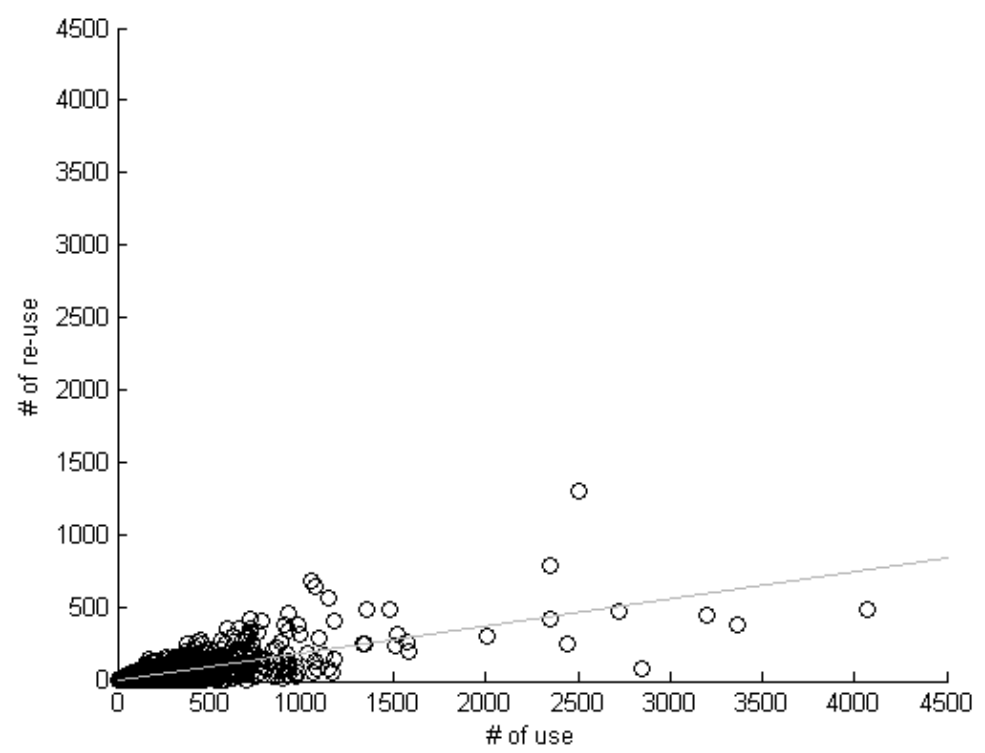

Figure 7: Use and re-use of securities

The scatter plot shows on the horizontal axis the total number of transactions, where a specific security was used and on the vertical axis the total number of transactions, where this specific security was re-used. Therefore, each point represents the number of uses and re-uses of a specific security. The grey line represents the least-squares fit with intercept -1.00 (Std. err. 0.564 ) and slope 0.19 (Std. err. 0.002). Overall, the plot indicates that there is no disproportionate re-use of specific securities. In total, there were 4,419 different securities used. The median security was used 44 times and re-used three times. 


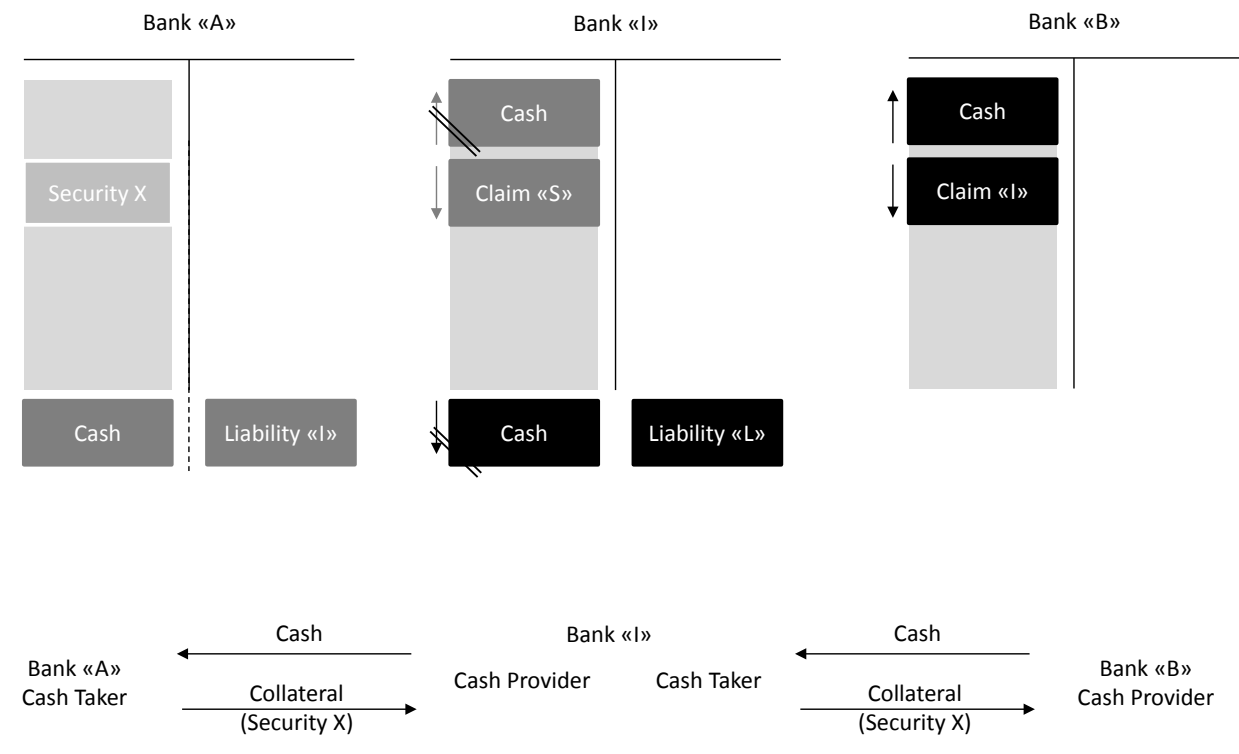

Figure 8: Balance sheet effects of repo transactions

The illustration is based on the prevailing accounting treatment of repo transactions (Wechsler, 1999). A repo transaction increases the cash taker's balance sheet, whereas it leads to a reallocation on the cash provider's asset side of the balance sheet. 


\section{Recent SNB Working Papers}

2015-2 Lucas Marc Fuhrer, Basil Guggenheim and Silvio Schumacher: Re-use of collateral in the repo market.

2015-1 Pinar Yeşin: Capital flow waves to and from Switzerland before and after the financial crisis.

2014-13 Thomas Nitschka: Have investors been looking for exposure to specific countries since the global financial crisis? - Insights from the Swiss franc bond market.

2014-12 Christian Grisse and Thomas Nitschka: Exchange rate returns and external adjustment: evidence from Switzerland.

2014-11 Rina Rosenblatt-Wisch and Rolf Scheufele: Quantification and characteristics of household inflation expectations in Switzerland.

2014-10 Gregor Bäurle and Daniel Kaufmann: Exchange rate and price dynamics in a small open economy - the role of the zero lower bound and monetary policy regimes.

2014-9 Matthias Gubler and Christoph Sax: Skill-Biased Technological Change and the Real Exchange Rate.

2014-7 Konrad Adler and Christian Grisse: Real exchange rates and fundamentals: robustness across alternative model specifications.

2014-6 Matthias Gubler: Carry Trade Activities: A Multivariate Threshold Model Analysis.

2014-5 Raphael A. Auer and Aaron Mehrotra: Trade linkages and the globalisation of inflation in Asia and the Pacific.

2014-4 Cyril Monnet and Thomas Nellen: The Collateral Costs of Clearing.
2014-3 Filippo Brutti and Philip Sauré: Repatriation of Debt in the Euro Crisis: Evidence for the Secondary Market Theory.

2014-2 Simone Auer: Monetary Policy Shocks and Foreign Investment Income: Evidence from a large Bayesian VAR.

2014-1 Thomas Nitschka: The Good? The Bad? The Ugly? Which news drive (co)variation in Swiss and US bond and stock excess returns?

2013-11 Linda S. Goldberg and Christian Grisse: Time variation in asset price responses to macro announcements.

2013-10 Robert Oleschak and Thomas Nellen: Does SIC need a heart pacemaker?

2013-9 Gregor Bäurle and Elizabeth Steiner: How do individual sectors respond to macroeconomic shocks? A structural dynamic factor approach applied to Swiss data.

2013-8 Nikolay Markov and Thomas Nitschka: Estimating Taylor Rules for Switzerland: Evidence from 2000 to 2012.

2013-7 Victoria Galsband and Thomas Nitschka: Currency excess returns and global downside market risk.

2013-6 Elisabeth Beusch, Barbara Döbeli, Andreas Fischer and Pınar Yeșin: Merchanting and Current Account Balances.
From 2015, this publication series will be renamed SNB Working Papers.

All SNB Working Papers are available for download at: www.snb.ch, Research

Subscriptions or individual issues can be ordered at: Swiss National Bank

Library

P.O. Box

$\mathrm{CH}-8022$ Zurich

Phone: +41 446313284

Fax: +41446318114

E-mail: library@snb.ch 
